\title{
'Babe': the Tale of the Speaking Meat: Part I
}

\author{
Val Plumwood
}

Excerpt from The Eye of the Crocodile (MS submitted for publication).

There is injustice for a communicative and ethical being in being conceived systematically in ways that refuse recognition of this status and these characteristics. There is injustice for such a being in being conceived reductively as body, first because such conception singles its referent out for treatment as radically less than it is, and second because such an instrumental reductionism defines the Other in terms that assume the right of a 'higher' group to treat them as a resource for their ends. Animals so conceived are subject to both radical exclusion (as having a radically different nature discontinuous from that of the human meat consumer) and homogenisation - they 'drown in the anonymous collectivity' of the commodity form meat. The radical exclusion aspect of the meat concept denies kinship and generates a conceptual distance or boundary between humanity and its 'meat' which blocks sympathy, reduces the risk of identification with those so designated, and silences them as communicative beings. The reductiveness of the meat concept permits a conceptual strategy designed to block recognition of these injustices, and its disruption in the concept of the speaking meat is one source of the flavour of paradox that lingers around that idea.

But from the injustice of industrial society's institution of meat as commodity, and the moral cowardice and evasion of the associated conceptual strategies of denial, we cannot conclude that there is no moral alternative to a universalised vegetarianism, that there are no other, less ethically problematic ways to resolve the tensions between conceiving non-humans both as communicative others and as food. In the complex biological exchange which sustains all our lives, we must all gain sustenance at the expense of the other, 'the one living the other's death, and dying the other's life', in the words of Heraclitus. Shagbark Hickory outlines an alternative, non-reductive perspective on this exchange which does not refuse the moral complexities and perplexities involved:

For most or all American Indians food (plant as well as animal) is kin. Relationships to plants and animals as, on the one hand, food and, on the other hand, kin creates a tension which is dealt with mythically, ritually, and ceremonially, but which is never denied. It is this refusal to deny the dilemma in which we are implicated in this life, a refusal to take the 
way of bad faith, moral supremacy, or self-deception which constitutes a radical challenge to our relationships to our food. The American Indian view that considerability goes "all the way down" requires a response considerably more sophisticated than those we have seen in the West, which consist either in drawing lines of moral considerability in order to create an out-group, or in constructing hierarchies of considerability creating de facto out-groups in particular cases. (Hickory)

Many forms of vegetarianism remain trapped in the western strategies of denial and radical exclusion which create further out-groups, merely redrawing the boundary of otherness in a different place, at the border of animality rather than humanity. In contrast, the indigenous recognition that the central philosophical problem of human life is that 'all our food is souls' points towards non-reductive practices and understandings of food that resolve the moral failings of 'bad faith, moral supremacy, [and] self-deception' Shagbark Hickory finds implicit in the dominant western meat concept. However, to the extent that these alternative understandings of food form part of a different 'form of life', in Wittgenstein's sense, they are not readily available, either practically or conceptually, within the context of contemporary industrial life and its commodified food relationships. Conversely, the fact that vegetarianism may usually be the course which, in the context of such a commodity society, will best minimise our complicity in injustice towards others does nothing to support the eurocentric conclusion that vegetarianism is a universal moral requirement for all people in all societies in all situations (Adams).

The paradox of the speaking meat is both the product of a particular social context, and a powerful symptom of some of the most indicative moral failings of that context. The western solution to the moral dilemmas of food is the creation of a set of moral dualisms, involving a sharp discontinuity between those who deserve and those who are beyond ethical consideration. As we have seen, the speaking meat forces us to confront the way this moral dualism and discontinuity is based on reductionism, denial and silencing. Our civilisation's orientation to the creation of moral dualisms may be one reason for its technological dominance, since it removes any constraints of respect which might otherwise hold back development, but it remains a major source of corruption of our ethical practices. The silencing solutions of moral dualism are always potentially capable of extension to selected groups of humans counted as lesser in their humanity, and we have seen this extension made many times in this century. This silencing possibility is always present, of course, in any human society, but it is greatly reinforced by the entrenchment of the dualist model in the basic case of food. 
Val Plumwood (1939-2008) was a founding intellectual and activist in the global movement that came to be known as ecofeminism. She published three major books as well as over a hundred articles and encyclopaedia entries, and her work has been translated into numerous languages.

\section{Works cited}

Adams, Carol. 'Ecofeminism and the Eating of Animals.' Hypatia 6.1 (1991): 125-145.

- The Sexual Politics of Meat: A Feminist-Vegetarian Critical Theory. New York: Continuum, 1990.

Hickory, Shagbark. 'Environmental Etiquette/Environmental Practice: American Indian Challenges to Mainstream Environmental Ethics.' The Company of Others: Essays in Celebration of Paul Shephard. Ed. Max Oelschlaeger. Durango, Colorado: Kivaki Press, 1995.

Wittgenstein, Ludwig. Philosophical Investigations. Oxford: Blackwell, 1954. 